\title{
Community-Based Conservation and Traditional Ecological Knowledge: Implications for Social-Ecological Resilience
}

\author{
Isabel Ruiz-Mallén $^{l}$ and Esteve Corbera ${ }^{1,2}$
}

\begin{abstract}
Our review highlights how traditional ecological knowledge influences people's adaptive capacity to socialecological change and identifies a set of mechanisms that contribute to such capacity in the context of community-based biodiversity conservation initiatives. Twenty-three publications, including twenty-nine case studies, were reviewed with the aim of investigating how local knowledge, community-based conservation, and resilience interrelate in social-ecological systems. We highlight that such relationships have not been systematically addressed in regions where a great number of community conservation initiatives are found; and we identify a set of factors that foster people's adaptive capacity to social-ecological change and a number of social processes that, in contrast, undermine such capacity and the overall resilience of the socialecological system. We suggest that there is a need to further investigate how climate variability and other events affect the joint evolution of conservation outcomes and traditional ecological knowledge, and there is a need to expand the current focus on social factors to explain changes in traditional ecological knowledge and adaptive capacity towards a broader approach that pays attention to ecosystem dynamics and environmental change.
\end{abstract}

Key Words: adaptive capacity; biodiversity conservation; community-based conservation; ecosystem services; local ecological knowledge; natural resource management; social-ecological change; social-ecological resilience; traditional ecological knowledge

\section{INTRODUCTION}

Researchers argue that the resilience of social-ecological systems is desirable for facilitating the sustainability of natural resources and ecosystem services and to ensure a stable environment for human life and well-being (Adger 2006, 2007). Ecological resilience is associated with ecosystem diversity and the stability of the ecosystems' functions and survival of keystone species. But the resilience of socialecological systems is also influenced by social factors, such as people's ability to anticipate changes and plan for the future (i.e., adaptive capacity), which is in turn shaped by human agency, institutional rules, and the level of exposure to and the impacts of global change on people's lives (Adger 2007, Nelson et al. 2007). Ecological and social resilience are thus dynamically interconnected through evolving forms of natural resource management and the subsequent response of biophysical systems.

In rural contexts, communities have often defined the spaces and the uses of natural resources according to their historical experience with disturbance and ecological surprise (Gadgil et al. 1993, Berkes et al. 2000, Colding et al. 2003, Folke et al. 2003, Toledo et al. 2003, Tompkins and Adger 2004, Berkes 2007). Local responses to socioeconomic and environmental change are mediated by formal and informal institutions, access to power and/or decision making over land and natural resources, as well as by existing ecological knowledge (HoltGimenez 2002, Adger et al. 2005, Eakin 2005, Lebel et al.
2006, Janssen et al. 2007, Naess 2012). In particular, traditional ecological knowledge lies behind the adaptive capacity of many rural and indigenous communities that have historically been able to conserve biodiversity while enhancing livelihoods and adapting to perturbations. Although some researchers use local ecological knowledge instead of traditional ecological knowledge because the term "traditional" is often associated with the concept of "indigenous", Olsson and Folke (2001) argue that local ecological knowledge differs from traditional ecological knowledge because the first might be a mix of scientific and practical knowledge whereas the second is not scientific. To avoid misunderstandings, in this review we adopt the widespread used term traditional ecological knowledge to refer to people's cumulative body of nonscientific knowledge, beliefs, and practice about local ecosystems and their management that evolves through social learning and adaptive processes, and which is supported by customary institutions and handed down through generations by cultural transmission (Ostrom 1990, Berkes 1993, Berkes et al. 2000).

In fact, several studies illustrate how this knowledge can contribute to deal with global change and to guide decision making regarding natural resource management and biodiversity conservation practices (Agarwal 2001, Colding et al. 2003, Mishra et al. 2003, Berkes 2007, Grant and Berkes 2007, Rai 2007). Such practices can include monitoring, temporal or total protection of species or habitats, multiple

\footnotetext{
${ }^{1}$ Institute of Environmental Science and Technology (ICTA), Universitat Autònoma de Barcelona, Spain, ${ }^{2}$ School of International Development, University of East Anglia, UK
} 
species management, resource rotation, succession management, and the social mechanisms behind them such as cross-scale institutions, taboos and regulations, rituals or ceremonies, and social and religious sanctions, among others (Berkes et al. 2000). In south and southeast Asia, for example, Colding et al. (2003) found that coastal communities holding inherited local knowledge of tsunamis were better in responding to such events and recovered quicker than other communities. In some instances, however, traditional ecological knowledge can undermine social-ecological systems resilience when, for instance, local people use their knowledge about wildlife to hunt or harvest indiscriminately for satisfying commercial demand (Gadgil et al. 2000, Fabricius et al. 2007).

At present, global environmental change is unfolding at an unprecedented speed, with current patterns of production and consumption, and the ensuing climate change, being the key causes and drivers (Wilk 2002, Pachauri and Reisinger 2007, Perry et al. 2010). Sociopolitical and economic processes operating at different spatial scales, such as increased logging pressure, agribusiness expansion, and land grabs, impact upon the ability of rural communities to access and sustainably manage formally owned and informally used resources (Dauvergne and Neville 2010, Yurdi and Heiner 2010, Cotula 2012, Scheidel and Sorman 2012). In many regions of the world, climate change is also contributing to transform ecosystems and species niches through altered rainfall and temperature patterns, thus having effects on the conditions for community-based conservation (McClanahan et al. 2008, Groves et al. 2012).

We understand community-based conservation to be any voluntary initiative of "natural resources or biodiversity protection conducted by, for, and with the local community" (Western and Wright 1994, p. 7). Community-based conservation aims "to enhance wildlife/biodiversity conservation and to provide incentives, normally economic, for local people" (Campbell and Vainio-Mattila 2003, p. 421). Community-based conservation can thus encompass a myriad of initiatives with different aims, governance systems, and levels of local decision-making power, ranging from selfregulated to comanaged conservation strategies (Dudley 2008). In self-regulated initiatives (i.e., community-managed forests, sacred forests, agropastoral systems, and small-scale fisheries), management authority and responsibility rest with rural communities and/or indigenous peoples (Dudley 2008) whose informal rules and social bonds can facilitate institutional flexibility to deal with rapid change (Folke et al. 2005). In comanaged initiatives (i.e., comanagement of protected areas), international and national agencies with the support of nongovernmental organizations (NGOs) promote community-based conservation by involving local people in decision making around natural resource management. These initiatives are sometimes developed to respond to the failure of top-down conservation models (Berkes 2004, 2007) or as a strategy to reinforce conservation initiatives led by selfgoverning communities (Armitage 2005). In both contexts, complex institutional mechanisms are designed to allocate management authority and responsibility among a plurality of actors (Dudley 2008), which can in turn draw upon both traditional ecological knowledge and scientific knowledge to define specific conservation strategies (Aswani et al. 2007, Mehring et al. 2011).

The interconnectedness between traditional ecological knowledge, adaptive capacity, and resilience in communitybased conservation initiatives is not yet well understood and it has not been systematically analyzed to date. Examining how traditional ecological knowledge shapes people's adaptive capacity patterns in community-based conservation initiatives regulated by different types of governance systems (i.e., self-regulated and comanaged) is critical to provide a nuanced understanding of the potential of and the limitations of traditional ecological knowledge in enhancing or limiting the ability of communities to deal with multiple stressors and sources of change. Through a review of scholarly literature that has simultaneously treated traditional ecological knowledge, adaptive capacity, and/or resilience in community-based conservation contexts, we discuss the interconnectedness between these three elements. We hypothesize that traditional ecological knowledge is conducive to favorable conservation outcomes and that it plays a more fundamental role in shaping people's adaptive capacity in the face of disturbance and crisis in self-regulated than in comanaged community-based conservation initiatives where other factors external to communities, such as formal institutional rules and scientific knowledge, may be more relevant in explaining positive adaptation.

Our review includes community-based conservation initiatives that involve rural and indigenous communities subject to varying degrees of ecological and socioeconomic perturbations, such as droughts, regulatory policies, market integration, religion, and migration. Scholars mostly rely on qualitative methods, and they less often combine the latter with on-site or secondary quantitative assessments of socialecological dynamics to discuss whether social-ecological systems are resilient. Traditional ecological knowledge appears as a crucial factor in both types of community-based conservation initiatives and can create synergies with other factors to enhance resilience in social-ecological systems. However, the latter can be undermined when the system is exposed to substantial perturbations, traditional institutions lose legitimacy, and natural resource management involves strict regulations.

The paper is organized as follows. The next section introduces the methodology for the review, whilst the third explains the results structured around two guiding questions: (1) What is the role of traditional ecological knowledge in successful 
conservation in self-regulated and comanaged communitybased conservation initiatives? and (2) How do traditional ecological knowledge- and potentially nontraditional ecological knowledge-related factors influence socialecological resilience in both types of initiatives? The fourth section discusses the findings and the last section concludes the paper.

\section{METHODS}

\section{Literature review}

To explore the evidence on the role of traditional ecological knowledge in community-based conservation and the latter's effects on adaptive capacity and resilience we conducted a review of academic journal articles published between January 2000 and January 2012. Previous articles were excluded because the resilience perspective influenced sustainability science and resource management studies in the late 1990s and because most empirical research on the issue has been developed in the last decade (Folke 2006). Relevant publications were identified by performing a keyword search in the ISI Web of Knowledge using the following key terms "comm*, conserv*, know*, AND adapt*". We used this database because it is one of the premier platforms covering most of the international and regional journals in every area of both natural and social sciences. Case study research published in nonpeer-reviewed journals, or in reports, books, or articles not indexed in the ISI Web of Knowledge were excluded. Given these limitations and the fact that some of the articles reviewed may have unintentionally omitted information relevant for this review, we suggest treating our results with caution.

From the first tranche of collected material we excluded articles from subject areas not related to natural resource management, such as genetics, biochemistry, and evolutionary biology. As a result we identified 532 articles. We then repeated our search using "resilien*" instead of "adapt*" and found 180 results that had also been picked up by our original search. Subsequently, the abstract of each identified article $(\mathrm{N}=532)$ was reviewed and 52 of them were fully considered as they reported case studies and addressed the three main topics of concern in this review, i.e., traditional ecological knowledge, resilience and/or adaptive capacity, and community-based conservation. Out of these 52, only 23 were included in our final analysis because they explicitly examined the role of traditional ecological knowledge in explaining positive or negative conservation outcomes and its contribution to adaptive capacity and social-ecological systems resilience in community-based conservation contexts. Among the discarded papers ( $\mathrm{N}=29$, see Appendix 1) fourteen did not analyze factors contributing to local adaptive capacity (including traditional ecological knowledge) when the system was altered by climate variability or other perturbations, six did not describe traditional ecological knowledge's contribution to adaptive management in community-based conservation initiatives, another six were not based on case study research, and three did not refer to explicit conservation outcomes.

\section{Analysis}

Twenty-nine case studies were thus analyzed from 23 selected publications. An identification number was assigned to each selected article. For articles reporting more than one case study, only those case studies addressing the two research questions highlighted in our introduction were included in the review. For instance, Gadgil et al. (2000) analyzed 52 case studies, but only three of them gave enough data for our analytical purposes.

Information on methodology, including study sites and data collection characteristics, was first tabulated with the aim of characterizing each article. To answer our first question we analyzed traditional ecological knowledge mechanisms supporting decision making and effective management of natural resources in conservation initiatives. We drew upon the four main levels of analysis defined by Berkes (1999) to address traditional ecological knowledge (i.e., empirical knowledge, world view, practical applications, and institutions), which we in turn labeled and codified as: (1) local observations, (2) rituals and ceremonies, (3) informal sanctions, and (4) customary institutions. For instance, Brewer's (2011) article on Maine's fisheries was coded as "local observations" because it only highlights the local knowledge on marine species as a component of traditional ecological knowledge contributing to community-based conservation. The study by Clark et al. (2008) focusing on the role of Inuit Qaujimajatuqangit as the totality of the traditional knowledge of the Inuit was coded using the four codes defined above. We also identified nontraditional ecological knowledge mechanisms contributing to effective communitybased conservation initiatives through the publications' data and created the following coding categories: (1) scientific information, (2) dominant religion, (3) formal regulations, and (4) official institutions. The study by McLeod et al. (2009), for instance, was coded as "dominant religion" because it describes the role of Christianity in supporting some of the traditional ceremonies and rituals that contribute to maintain customary marine resource management and the conservation system in an Indonesian village.

To answer our second question and discuss which factors including traditional ecological knowledge contribute to adaptive capacity and social-ecological resilience in selfregulated and comanaged community-based conservation initiatives we developed coding categories based on Berkes et al. (2000): (1) decisions based on local experience, (2) respect of local institutions, (3) flexible institutional decision making, (4) trust and social bonds, (5) local leadership, (6) power sharing, and (7) mutual learning. Finally, we had additional 
codes to describe nontraditional ecological knowledge factors affecting resilience that are related to the type of perturbation as described by the reviewed papers, including: (8) official regulations, (9) dominant religion, (10) climate change, and (11) market integration. All information was coded by the first author of the paper and was validated by the second author.

\section{RESULTS}

\section{Research origins and foci}

Table 1 describes study site characteristics and summarizes information on methodological issues of the 29 selected case studies. The table covers 19 community-based conservation initiatives where decision making relies on customary institutions, sometimes supported by NGOs $(n=6)$, and ten initiatives of comanagement involving local managers and governments (five with the support of NGOs).

Twenty case studies were situated in tropical regions, mainly in south, southeast, and east Asia $(n=16)$. Three case studies were located in Oceania and there was only one case study for Latin America, Europe, and Africa. India $(n=6)$ and Canada $(n=5)$ hosted more case studies. Canadian research groups led most publications, followed by U.S. researchers ( 7 and 6 articles out of 23, respectively) whereas Latin American and African institutions led none.

Research was conducted at local and regional levels (with 13 and 8 articles, respectively) rather than at the national scale ( 2 articles). Case studies concerned both terrestrial $(n=15)$ and aquatic $(n=14)$ biomes. In terrestrial biomes, articles examined agroforestry and forestry systems, focusing at the ecosystem level rather than the species level (i.e., forest cover change) to understand conservation outcomes and interpret socialecological resilience. In aquatic environments, studies frequently analyzed coral reefs and lagoon fisheries, as well as marine wildlife management systems, where conservation efforts focused at the species level (i.e., parrotfish, polar bears, marine turtles). Reported conservation outcomes were assessed directly through recall in several case studies $(n=16)$ whereas only five assessed ecological factors of the targeted species. In other cases $(n=9)$ conservation outcomes were referred to data collected by other researchers.

Most case studies analyzed more than one perturbation as drivers of change in social-ecological systems. Research was predominantly concerned with rural communities' ability to adapt to opening markets for agricultural, marine, and forest resources $(n=20)$. Ten case studies also highlighted the consequences of political stressors in community-based conservation initiatives (i.e., land-use policy changes), eight case studies analyzed socio-cultural perturbations (i.e., population growth, religion conversion) and four examined the effects of climate change (e.g., reduction of sea ice) in the system's resilience.
Nine of the 29 case studies reviewed lacked detail on research designs and methods (i.e., sample size, period of data analysis, interview templates, and coding frameworks for content analysis). Many relied on qualitative data $(n=22)$ gathered through ethnographic tools (i.e., interviews, participant observation) and reviews of existing gray literature (i.e., reports, articles, archival data). Quantitative data of socialecological systems were collected in seven case studies through surveys, satellite imagery analysis, or biological monitoring. The surveys collected information on local people's livelihood options at household level. However, only one study reported quantitative data regarding fishing families' socioeconomic differences in accessing and using natural resources, which were in turn related to various households' adaptive management strategies (ID\#10).

Collected data were often used to conduct historical analyses of the links between traditional ecological knowledge and community-based conservation in shaping adaptive capacity at community level. Based on past experience, the robustness of community-based conservation in the future was then tentatively inferred, and policy and management recommendations were provided in order to cope with future perturbations. The reinforcement of sustainable traditional fishing practices and institutions by statutory law (ID\#10 and $\# 14-1$ ), the involvement of local people in decision making and forest management in protected areas (ID\#11 and \#19), or the improvement of cross-scale communication and information exchange between governments, scientists, and communities on polar bears and goose populations in arctic regions (ID\#8 and \#18) are examples of such recommendations.

\section{Exploring the relationships between traditional ecological knowledge and community-based conservation}

Decision making around natural resource management based on traditional ecological knowledge was identified as a key factor contributing to successful conservation in both types of community-based conservation initiatives. Local communities were involved in a process of social learning through the transmission and sharing of such knowledge and ideas. The role of traditional ecological knowledge, however, was more fundamental in self-regulated than in comanaged initiatives in which other social mechanisms supported decision making for effective conservation (Table 2).

In the case of self-regulated community-based conservation initiatives, research highlighted that traditional ecological knowledge has been historically instrumental in ensuring biodiversity conservation and enhancing local livelihoods. Biodiversity monitoring based on local observations, taboos and regulations, informal sanctions, customary institutions defining decision making, and rituals and ceremonies enforcing behavior that supports conservation goals were 


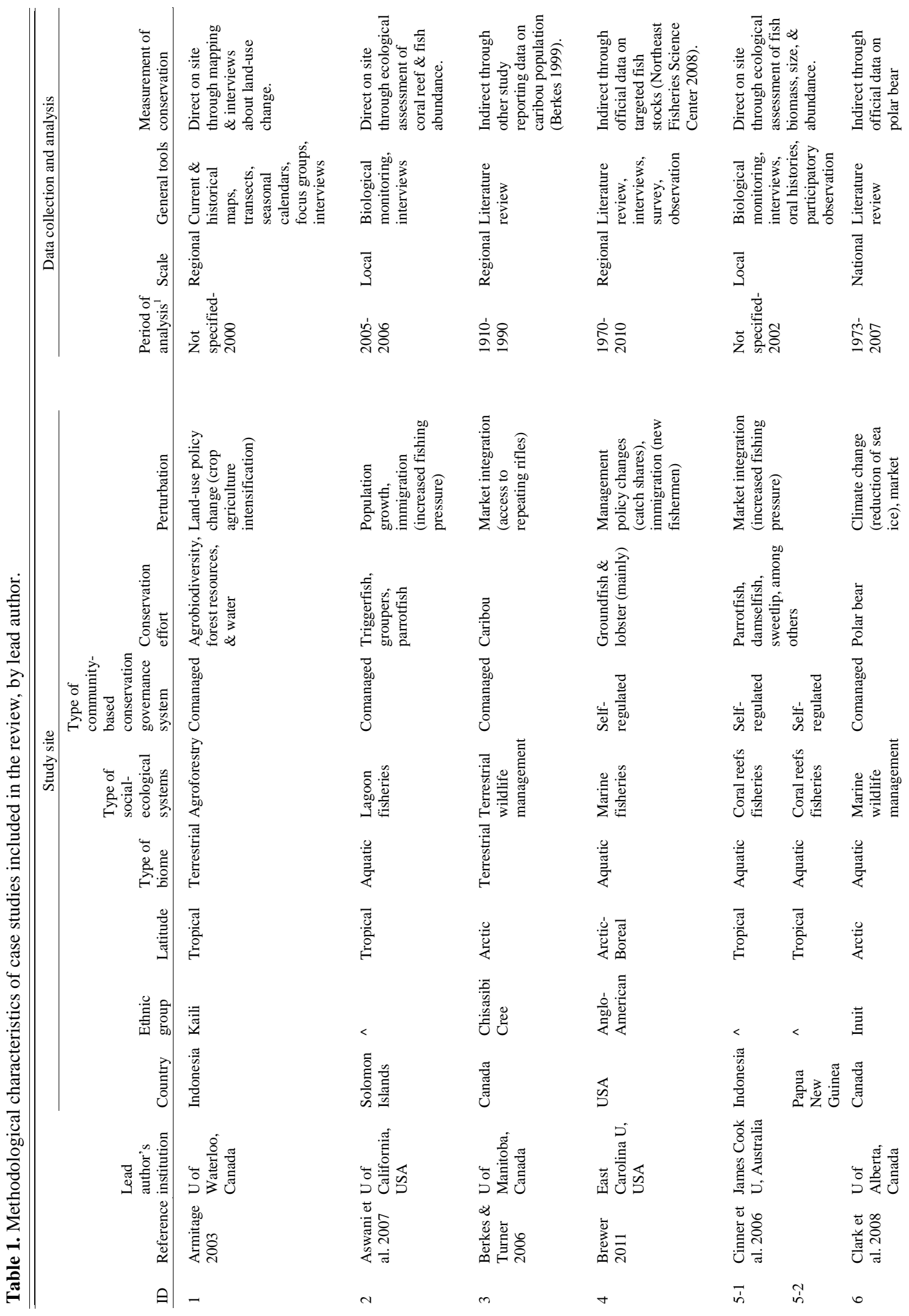



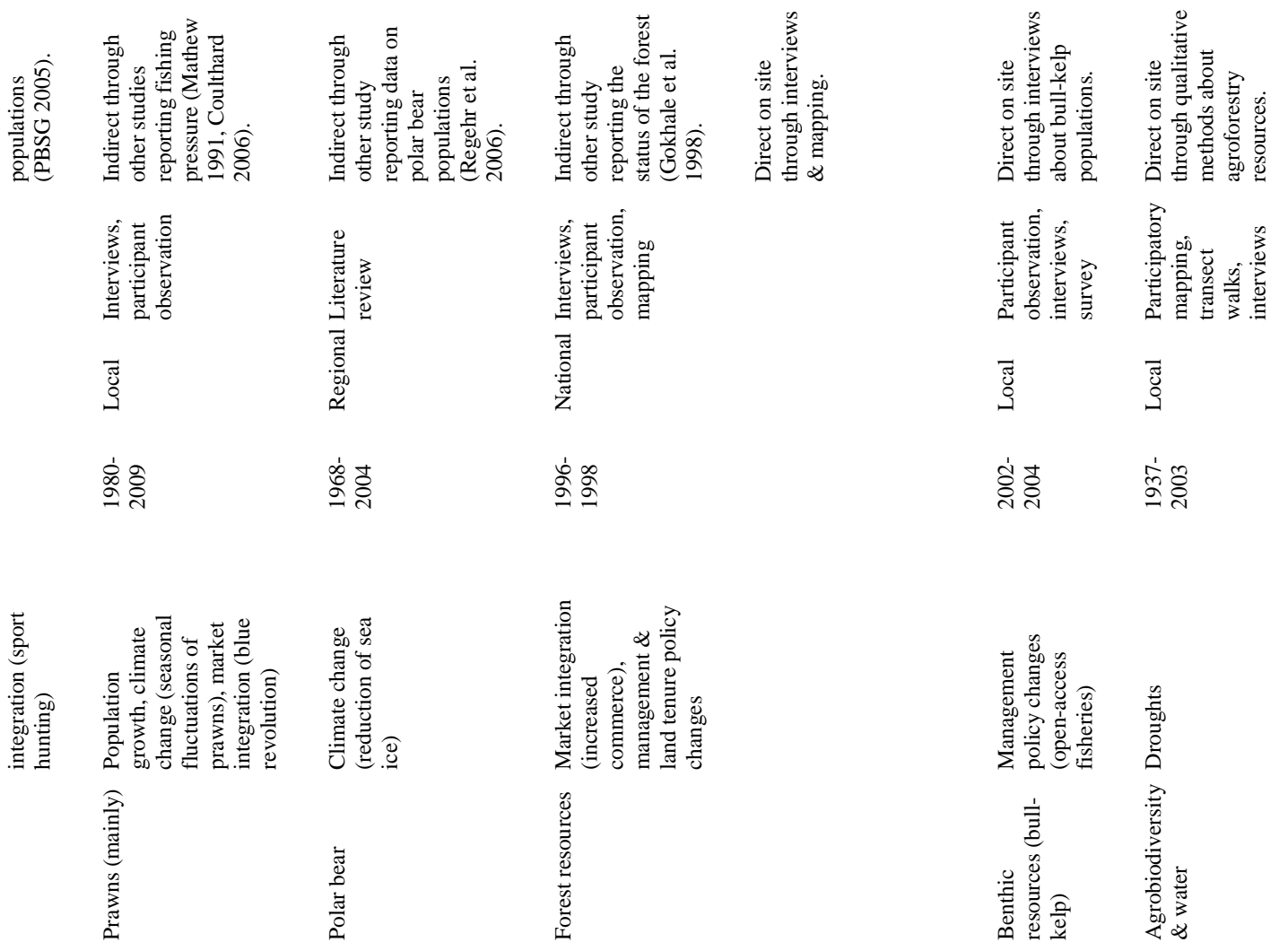

荘

离

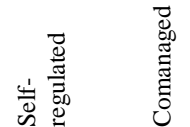

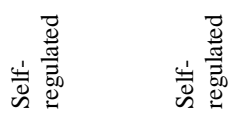

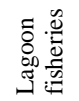
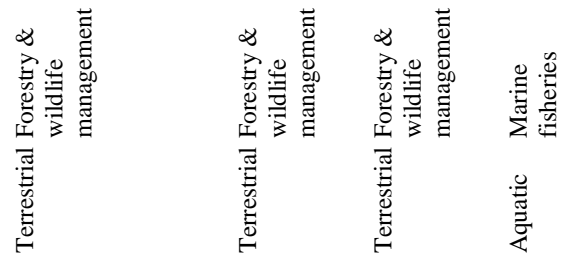

है

:

苟

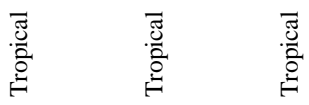

률

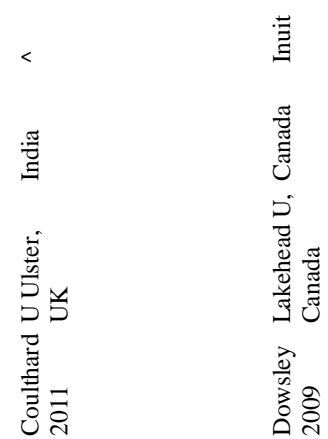

愛

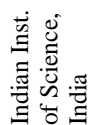

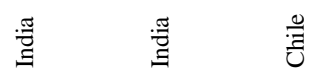

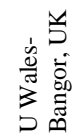

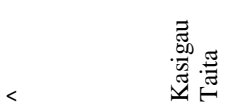

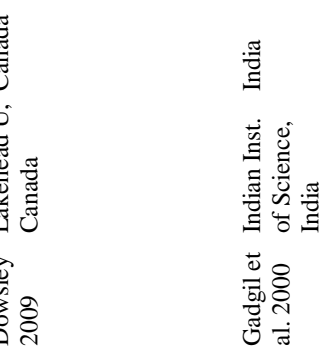

$r$

ó

2 2

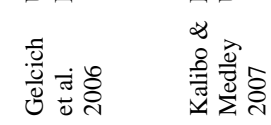


WUn

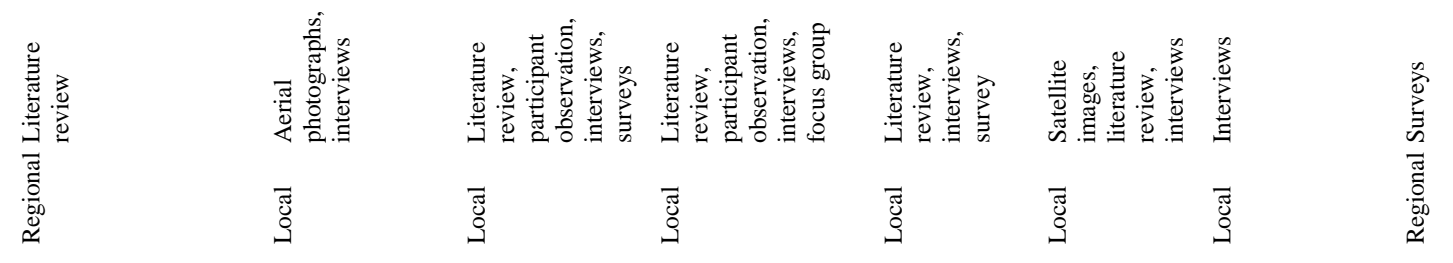

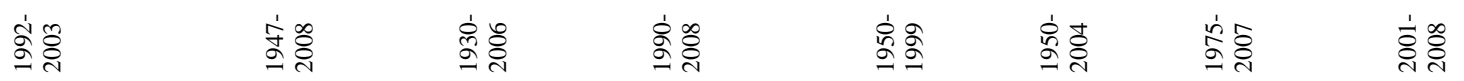

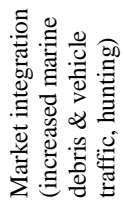

站

$\frac{n}{m}$

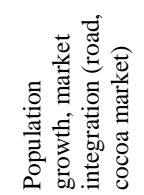

$\sqrt{1}$

高部

Mente

I

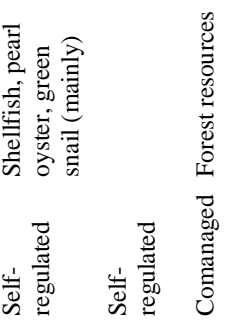

竞旁

:

离

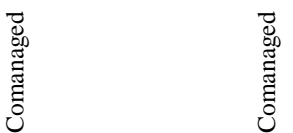

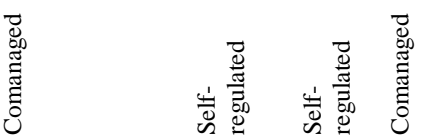

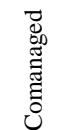

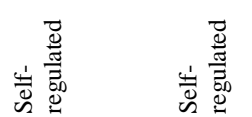

焉

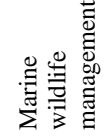

爵

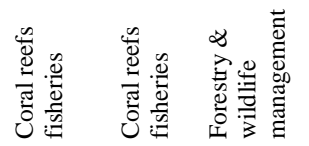

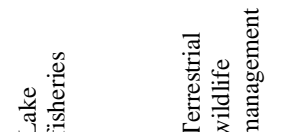

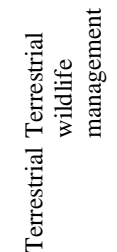

冚

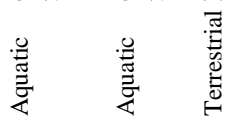

军

胥

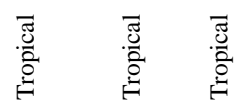

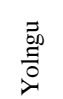

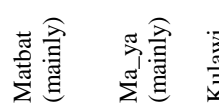

ฮ్ర

苞

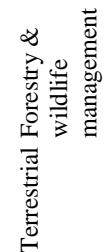

.

竎

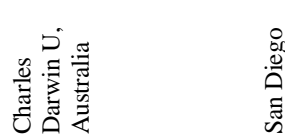

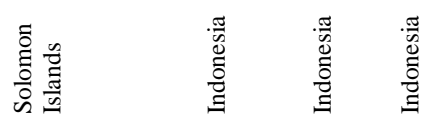

害产

焉

$\stackrel{Ð}{0}$

然然

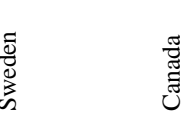

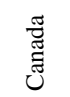

药

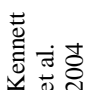

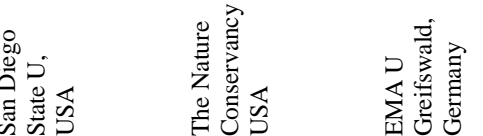

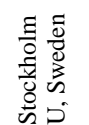

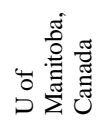

万人

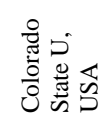

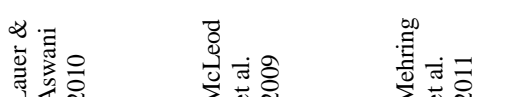

悹

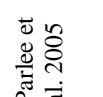

言竞

量

工

$\rightarrow$ I $\stackrel{\text { I }}{ \pm}$

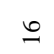

$=$

$\stackrel{\infty}{-1}$

2 

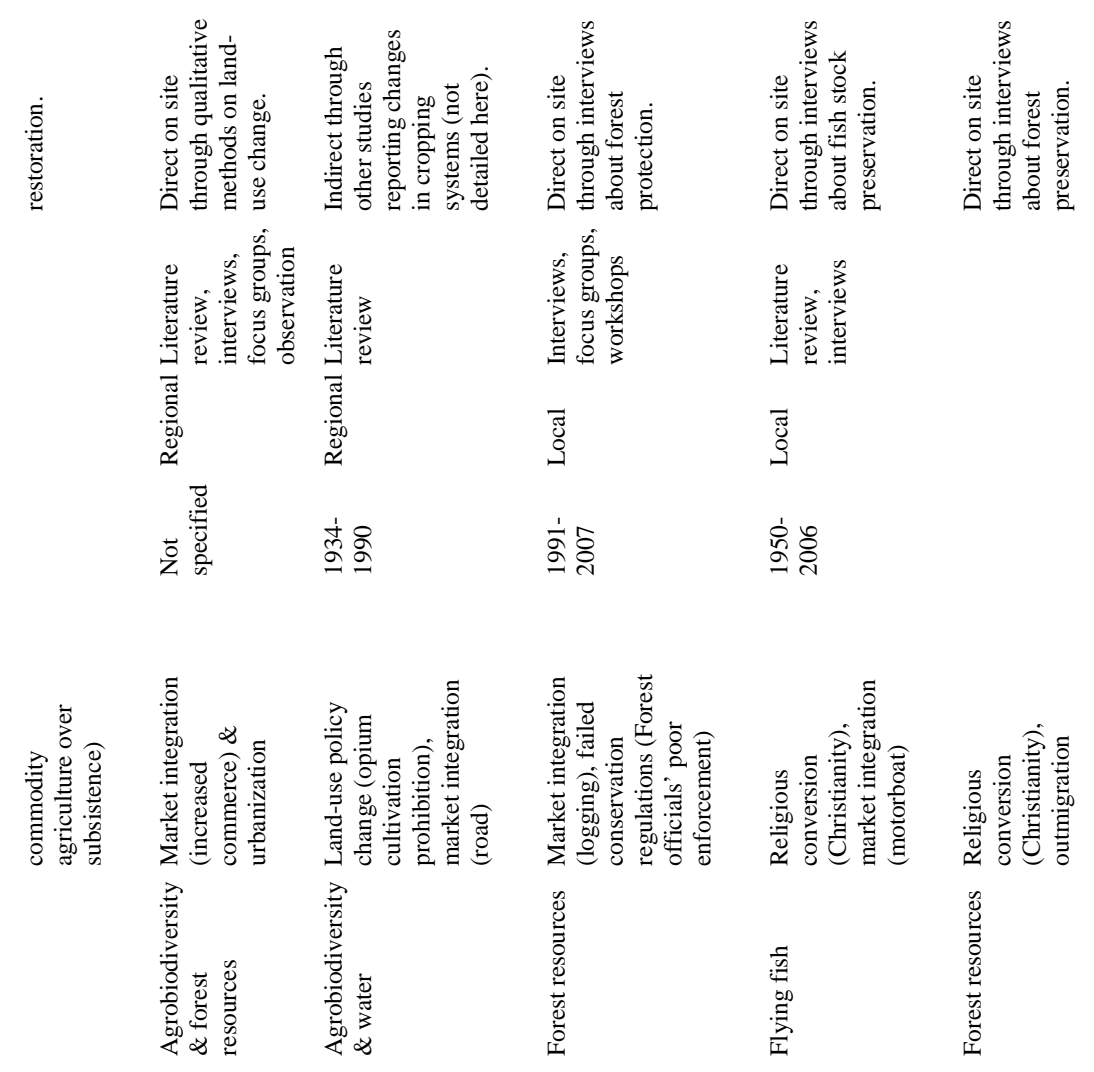

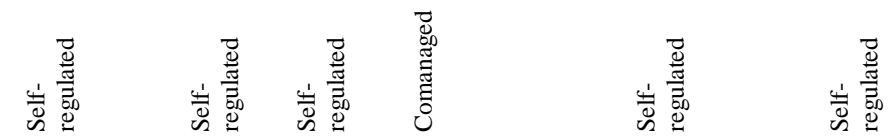

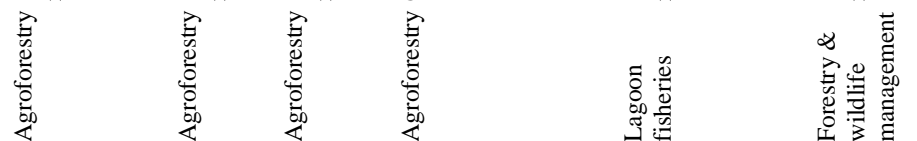

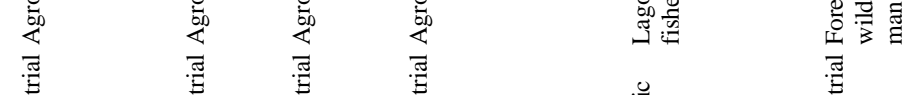

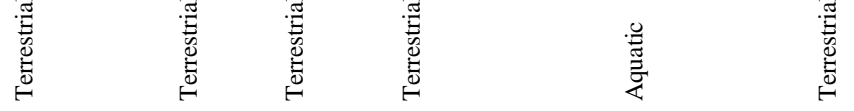

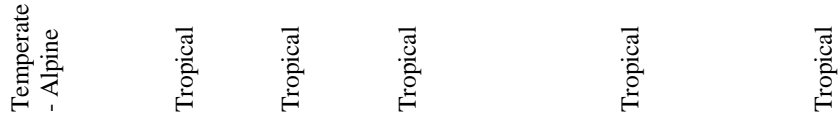

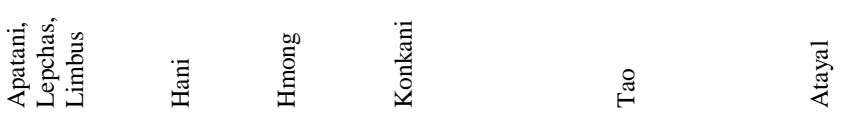

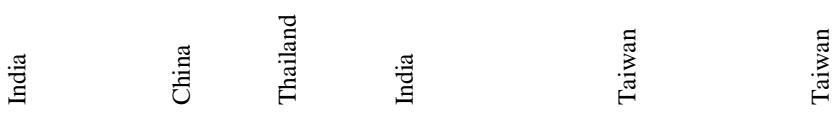

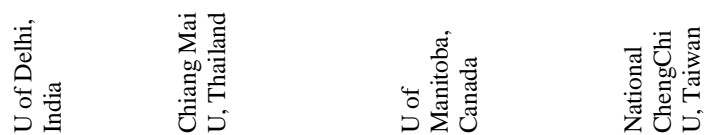

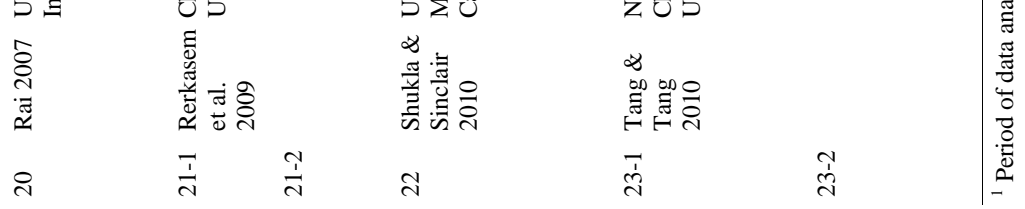


identified as key processes sustaining natural resource management. Case studies in Indonesia and Papua New Guinea, for example, documented positive effects on reef resources of periodic closures managed through a body of traditional ecological knowledge that allowed for the rapid assessment of fisheries' conditions (ID\#5-1 and \#5-2). Village farmers in the Chinese province of Yunnan operated mixed farming systems based on their knowledge about forest regeneration, which was a key component in determining the sustainability of shifting cultivation systems (ID\#21-1). Animistic beliefs and ceremonies played an important role in forest protection and sustainable land use in the Indonesian region of Banawa-Marawola. Villagers did not cut large trees because they held the belief that trees were spirits that would punish them by causing sickness and damage to crops (ID\#1). In a few cases other factors, such as collaboration with scientists $(n=2)$, the dominant religion principles $(n=2)$ and formal institutions $(n=2)$, also contributed to successful conservation outcomes. For example, Indonesian laws on the management of fisheries provided a legal basis for supporting traditional rights over coastal waters, which contributed to communities' maintenance of sustainable and customary resource management practices (ID\#14-1 and \#14-2). However, documented trade-offs between traditional ecological knowledge and community-based conservation in self-regulated initiatives were related to the formalization of such initiatives by national agencies. For example, the creation of a management and exploitation area for benthic resources in Chile invalidated prior informal regulations and rules and imposed regulations on access rights, thereby excluding traditional ecological knowledge from formal decisionmaking procedures over catch arrangements (ID\#10).

In comanaged, community-based conservation initiatives, which combine traditional and official regulations as well as informal and formal sanctions established by cross-scale institutions, traditional ecological knowledge was considered the basis for sound decision making around natural resource management, alongside scientific knowledge. For example, in the Swedish Lake Racken, self-organized local institutions recognized the value of traditional knowledge and management rules for crayfish, which were in turn influenced and regularly reshaped by changes in sanctions, local monitoring data, scientific information, and the practices of governmental authorities (ID\#16). A seemingly successful example was the comanagement of caribou populations in Hudson Bay and James Bay, Canada, which relied on local elders to regulate young people's overhunting. Elders relied on oral history and Cree ethics to make young hunters aware of the importance of following traditional hunting standards with the aim of sustaining wildlife and resources (ID\#3). A shift in the governance of such type of initiatives, however, can undermine the role of customary institutions in decision making and weaken traditional ecological knowledge. The failure of a comanagement regime for polar bear management due to policy conflicts and detrimental effects on Inuit Qaujimajatuqangit has also been documented (ID\#6).

\section{Factors explaining resilience in community-based conservation}

All the studies reviewed claimed to address the concept of resilience from a social-ecological perspective, i.e., they referred to both ecosystem capacity and communities' ability to adapt positively to a perturbation whilst maintaining social functions and conservation outcomes. Twenty-two case studies reported resilient systems to perturbations: 14 of them in self-regulated community-based conservation and eight in comanaged initiatives. Seven cases reported social-ecological systems that failed to adapt to a given perturbation (Table 3 ). Methodologically, however, only 5 among the 29 cases reviewed, which were concerned with fisheries, systematically analyzed ecological attributes and ecosystem dynamics. Among these, only one examined resilience over a period of 60 years (ID\#13) whereas three studies limited the analysis to short-term processes of <3 years (ID\#2, \#5-1, and \#5-2) and the other did not specify the period of data analysis (ID\#10). The remaining 24 cases relied on interviews, historical maps, and oral histories to discuss only social elements of resilience, such as knowledge systems and governance issues, usually over periods $>30$ years $(n=16)$. The latter may lead to underestimating the role of ecological dynamics in adaptation and/or to misrepresenting the role of social attributes in explaining social-ecological systems resilience.

Generally speaking, the publications reviewed considered self-regulated initiatives resilient to a given (set of) perturbation(s) when such initiatives held some of the following traits related to traditional ecological knowledge: (1) they maintain a decision-making system, based on local observations, beliefs, and perceptions, that guarantees the conservation status of a resource; (2) in decision making, they respect the role of customary institutions that rely on cultural values (i.e., sharing and reciprocity), taboos, and customary sanctions, which also hold the transmission of the cumulative body of ecological knowledge; (3) they have developed an institutional learning and have integrated formal and informal mechanisms for flexible and rapid decision making; (4) they have reinforced community networks through trust building and social bonds to incentivize regulatory compliance; and (5) they are guided by local leaders who have a commitment to their community traditions and cultural values and who support sustainable management practices to enhance both the well-being of local people and biodiversity conservation. For example, Cree geese hunters in Canada relied on social memory and exchange of ecological observations to track geese population changes and related the latter to ecological disturbances. This knowledge allowed hunters to continuously adapt management strategies and reduce hunting pressure in the light of changing environmental conditions (ID\#18). Also 
Table 2. Decision-making mechanisms contributing to sustainable natural resource management and conservation, by type of community-based conservation governance system.

\begin{tabular}{|c|c|c|c|c|c|c|c|c|}
\hline \multirow[t]{2}{*}{ ID } & \multicolumn{4}{|c|}{ Traditional ecological knowledge-related } & \multicolumn{4}{|c|}{ Nontraditional ecological knowledge } \\
\hline & $\begin{array}{c}\text { Local } \\
\text { observations }\end{array}$ & $\begin{array}{l}\text { Rituals and } \\
\text { ceremonies }\end{array}$ & $\begin{array}{l}\text { Informal } \\
\text { sanctions }\end{array}$ & $\begin{array}{l}\text { Customary } \\
\text { institutions }\end{array}$ & $\begin{array}{c}\text { Scientific } \\
\text { information }\end{array}$ & $\begin{array}{l}\text { Dominant } \\
\text { religion }\end{array}$ & $\begin{array}{c}\text { Formal } \\
\text { regulations }\end{array}$ & $\begin{array}{c}\text { Official } \\
\text { institutions }\end{array}$ \\
\hline
\end{tabular}

\begin{tabular}{|c|c|c|c|c|c|c|c|c|}
\hline \multicolumn{9}{|c|}{ Self-regulated community-based conservation } \\
\hline 1 & + & + & + & + & & & & \\
\hline 4 & + & & & & + & & & \\
\hline $5-1$ & + & + & + & + & & & & \\
\hline $5-2$ & + & + & + & + & & & & \\
\hline 7 & + & & + & + & & & & \\
\hline $9-1$ & & + & + & + & & & & \\
\hline $9-2$ & & & + & + & & & & \\
\hline 10 & + & & & & + & & & \\
\hline 11 & + & + & + & + & & & & \\
\hline $14-1$ & + & + & + & + & & + & + & \\
\hline $14-2$ & + & + & + & + & & & + & \\
\hline 17 & + & + & + & + & & & & \\
\hline 18 & + & + & + & + & & & & \\
\hline 19 & + & & & & & & & \\
\hline 20 & & + & + & + & & & & \\
\hline $21-1$ & + & & + & + & & & & \\
\hline $21-2$ & + & & + & + & & & & \\
\hline $23-1$ & + & + & + & + & & & & \\
\hline $23-2$ & + & + & + & + & & + & & \\
\hline \multicolumn{9}{|c|}{ Comanaged community-based conservation } \\
\hline 2 & + & + & & + & + & & + & + \\
\hline 3 & + & & + & + & + & & & + \\
\hline 6 & + & + & + & + & + & & + & + \\
\hline 8 & + & & + & + & + & & + & + \\
\hline $9-3$ & & + & + & + & & & & \\
\hline 12 & + & + & + & + & + & & + & + \\
\hline 13 & + & + & + & + & + & & + & + \\
\hline 15 & + & & + & + & & & + & \\
\hline 16 & + & + & + & + & + & & + & + \\
\hline 22 & + & & + & + & + & & + & + \\
\hline
\end{tabular}

in Canada, the Denésoliné traditional system for monitoring movements of caribou allowed the Denésoliné to deal with variability in species' migration patterns by organizing to observe, and communicate and learn about, caribou movements through periodic meetings during hunting (ID\#17).

In co-managed regimes, reviewed articles pointed out two additional traits that contribute to social-ecological systems resilience: 6) they rely on cross-institutional collaboration between customary and government institutions, often supported by research groups and NGOs, to make deliberative decisions that provide opportunities to deal with change; and 7) they involve a process of mutual learning, reinforced through the creation of knowledge networks between scientists and local managers that are complementary to existing forms of institutional learning and knowledge sharing of local communities. For example, institutional learning capacity characterized the Baripada Forest Adaptation Initiative, an Indian comanaged community-based conservation effort in northeast India that adapts local rules to changing social-ecological conditions in village forests. In 2002, an increase in family size and forest cover led them to extend the period for removing fuel wood by one month (ID\#22).

Diminished resilience in five self-regulated community-based conservation initiatives was explained by the failure of local communities to deal with internal and external processes that were altering local behavior or the conditions of resource management. In Fanfanlap, Indonesia, local leadership undermined the legitimacy of customary institutions, thereby contributing to the erosion of community-based conservation 
Table 3. Reported factors enhancing resilience (+) and undermining resilience (-) in the context of community-based conservation (CBC) initiatives, by type of community-based conservation governance system.

\begin{tabular}{|c|c|c|c|c|c|c|c|c|c|c|c|c|c|}
\hline \multirow[b]{2}{*}{$\mathrm{CBC}$} & \multirow[b]{2}{*}{ ID } & \multirow[b]{2}{*}{ Resilient } & \multicolumn{5}{|c|}{ Factors based on traditional ecological knowledge } & \multicolumn{2}{|c|}{$\begin{array}{c}\text { Factors including } \\
\text { traditional ecological } \\
\text { knowledge }\end{array}$} & \multicolumn{4}{|c|}{ Nontraditional ecological knowledge factors } \\
\hline & & & $\begin{array}{c}\text { Decisions } \\
\text { based on } \\
\text { local } \\
\text { experience }\end{array}$ & $\begin{array}{l}\text { Respect of } \\
\text { local } \\
\text { institutions }\end{array}$ & $\begin{array}{c}\text { Flexible } \\
\text { institutional } \\
\text { decision } \\
\text { making }\end{array}$ & $\begin{array}{l}\text { Trust and } \\
\text { social } \\
\text { bonds }\end{array}$ & $\begin{array}{c}\text { Local } \\
\text { leadership }\end{array}$ & $\begin{array}{l}\text { Cross-scale } \\
\text { institutions }\end{array}$ & $\begin{array}{l}\text { Collaboration } \\
\text { with } \\
\text { scientists }\end{array}$ & $\begin{array}{l}\text { Government } \\
\text { regulations }\end{array}$ & $\begin{array}{l}\text { Religion } \\
\text { conversion }\end{array}$ & $\begin{array}{l}\text { Climate } \\
\text { change }\end{array}$ & $\begin{array}{c}\text { Market } \\
\text { integration }\end{array}$ \\
\hline \multicolumn{14}{|c|}{ Self-regulated } \\
\hline & 1 & Yes & + & + & & & - & & & - & & & \\
\hline & 4 & No & & + & & + & & & + & - & & & - \\
\hline & $5-1$ & Yes & + & + & + & + & + & & & & & & \\
\hline & $5-2$ & Yes & + & + & + & + & + & & & & & & \\
\hline & 7 & Yes & + & + & + & + & & & & & & & \\
\hline & $9-1$ & Yes & + & + & + & + & & & & - & & & \\
\hline & $9-2$ & Yes & + & + & + & + & + & & & - & & & \\
\hline & 10 & No & & & + & & & & + & - & & & - \\
\hline & 11 & Yes & + & + & + & & & & & & & & \\
\hline & $14-1$ & Yes & + & + & + & + & + & & & + & + & & \\
\hline & $14-2$ & No & & & + & & - & & & + & - & & - \\
\hline & 17 & Yes & + & + & + & + & & & & & & & \\
\hline & 18 & Yes & + & + & + & & & & & & & & \\
\hline & 19 & No & + & + & & + & & & & - & & & \\
\hline & 20 & Yes & + & + & + & + & & & & & & & \\
\hline & $21-1$ & Yes & + & + & + & + & & & & & & & \\
\hline & $21-2$ & Yes & + & + & + & & & & & & & & \\
\hline & $23-1$ & No & & & & + & & & & & - & & - \\
\hline \multirow{2}{*}{\multicolumn{14}{|c|}{ Comanaged }} \\
\hline & & & & & & & & & & & & & \\
\hline & 2 & Yes & + & + & + & + & & + & + & & & & \\
\hline & 3 & Yes & + & + & + & & & - & + & + & & & \\
\hline & 6 & No & + & & & + & & + & + & - & & - & - \\
\hline & 8 & Yes & & + & + & + & & + & + & + & & & \\
\hline & $9-3$ & No & & & & & & - & & - & & & - \\
\hline & 12 & Yes & + & + & + & & & + & + & + & & & \\
\hline & 13 & Yes & + & + & + & & & + & + & + & & & \\
\hline & 15 & Yes & + & + & & + & + & + & & & & & \\
\hline & 16 & Yes & + & + & + & & + & + & + & + & & & \\
\hline & 20 & Yes & + & + & + & + & + & + & + & + & & & \\
\hline
\end{tabular}

and the weakening of local communities' adaptive capacity to cope with economic and socio-cultural change. The corruption of the local leader was translated in a loss of social trust and, subsequently, the sasi (i.e., the local customary marine tenure system) became contested and led to over fishing (ID\#14-2). Changes in religious beliefs can also weaken the adaptive capacity of social-ecological systems to external pressures. On a tourist island of Taiwan, for example, Christianity replaced the Tao belief system; consequently, traditional rules, taboos, and ceremonies governing the use of the coastal fishery have progressively lost importance against other values. Young people are now catching flying fish with motorboats and trading with tourists, which is leading to the depletion of fish stocks (ID\#23-1). Finally, strong imposition of official management regulations can also jeopardize local adaptive capacity, as shown by the case of catch shares imposed in Maine's fisheries to protect groundfish populations. Catch shares excluded local knowledge, social rules, and informal sanctions from decision-making processes, and failed to sustain fish populations and fishermen's livelihoods (ID\#4).
Lack of resilience was also documented in two case studies of comanaged community-based conservation: one in Canada (ID\#6) and one in India (ID\#9-3). In northern Canada, factors undermining resilience were related to power-sharing conflicts between Inuit people and conservation managers (that is, environmental NGOs and scientists), which were explained by competing perspectives on polar bear management and conservation. Such conflicts were fueled by lack of transparency, communication, and trust between local people and policy makers, and weakened adaptive capacity to cope with change and achieve conservation outcomes. Additionally, the rapid reduction of sea ice-affecting polar bear survival and the increasing market for sport huntedtrophies that translate into income opportunities for local people- have also had a negative impacts on social-ecological systems resilience. Similarly, in a village in Rajasthan in northwest India, community-conserved areas of sacred groves became government property after a land-reform policy was enacted. Formal conservation regulations subsequently undermined the role of traditional leaders in regulating 
harvesting in the groves and led to the degradation of existing sites.

\section{DISCUSSION}

The results presented above indicate that traditional ecological knowledge plays a more important role in enhancing local people's adaptive capacity to new social-ecological challenges in self-regulated community-based conservation initiatives than in comanaged community-based conservation initiatives where collaboration with government and scientists play a more central role. Furthermore, the review suggests the existence of four critical mechanisms through which traditional ecological knowledge results in positive adaptation in contexts of community-based conservation. First, people have the capacity to elaborate knowledge about ecosystems by testing it iteratively, as well as to learn from crises and management mistakes. Second, they are able to transmit and guard it locally, with the aim of adjusting management practices to new social-ecological states arising after perturbations. These two mechanisms are related to the dynamic nature of local knowledge (Evans et al. 2011, GómezBaggethun and Reyes-Garcia 2013) Third, an appropriate interpretation of ecosystem change is related to the traditional ceremonies and rituals that contribute to the cultural internalization of conservation rules. And fourth, such rules are the basis of flexible decision making. This is consistent with previous studies that have identified the linkages between local knowledge and resilience in social-ecological systems (Berkes et al. 2000, Folke et al. 2005). A review conducted by Berkes et al. (2000), for example, also identified the use of rules supported by customary institutions, rituals, and other traditions; flexibility in decision making; accumulation of ecosystem knowledge; and diversification of livelihood strategies as key mechanisms used by local people to cope with dynamic change in traditionally managed systems. In a recent study, Gómez-Baggethun et al. (2012) also identified these coping mechanisms as instrumental elements of traditional resource management in Spain's National Park of Doñana. Particularly in community-based conservation contexts, reported outcomes of the reviewed case studies suggest that, even though current environmental change is faster than the processes of generating and transmitting traditional ecological knowledge, many communities engaged in community-based conservation have been able to learn from experience and errors, engage young people in this learning process, and innovate and generate new knowledge to overcome crisis.

Traditional ecological knowledge mechanisms that enhance resilience are also present in comanaged conservation initiatives. In general, cross-scale institutions and official regulations have had positive effects on both traditional ecological knowledge and local adaptive capacity. However, our review also shows that these mechanisms can be undermined when a community-based conservation initiative is formally established, particularly if the latter involves strict regulations enacted by external actors. Rigid management and governance structures can sometimes constrain people's ability to respond to changing conditions because such structures are slow in learning from past experience and they innovate through new institutional arrangements (Brewer 2011). Although official regulations are indeed important for addressing international obligations and priorities and for complying with national policies on biodiversity conservation, the practical implementation of these regulations can result in conflicts among stakeholders and have detrimental effects on their well-being and biodiversity conservation. In indigenous territories, this is not new given that comanagement approaches often lie behind the failure of many integrated conservation and development projects (Brown 2002). In response to that, some researchers have argued for flexible, multilevel conservation models involving the devolution of power to local communities (Berkes 2010, Folke et al. 2005). Such approach requires the input and knowledge of local people that should be embraced and considered a key tool for deliberation and not an alternative if science fails (Berkes 2007). To create the conditions for the successful harmonization of traditional ecological knowledge and community-based conservation initiatives, social sources of resilience, such as social memory and social capital, should then be guaranteed and strengthened (Folke et al. 2005). Moreover, the presence of enforcement mechanisms that prevent free-riding behavior and that reinforce trust, sense of community, and social networks among local stakeholders and between local people and governments is another important requirement for effective community-based conservation (Ostrom 1990). This challenge involves neither centralization nor decentralization of power, but the linking traditional ecological knowledge with flexible institutions and multilevel governance systems for building trust through adaptive governance systems (Folke et al. 2005). This also implies a previous understanding of the local interests, institutions, and power relations that make adaptation difficult (Naess 2012).

The results presented also suggest that resilience theory and robust methodological approaches have yet to figure prominently in community-based conservation research. The ecological attributes of a system that are important for understanding resilience were hardly assessed in the studies reviewed and their analyses were limited to short periods of time. Climate variability and shocks figured as less analyzed stressors to traditional ecological knowledge and communitybased conservation than socioeconomic and political issues. Only four reviewed case studies, most of which were conducted in the Arctic, paid attention to climate-related events and trends as key factors behind the weakening of traditional ecological knowledge and community-based conservation objectives. Scholars have already paid attention to comparing adaptive management strategies to climate 
variability and environmental change in rural Africa (Goulden et al. 2009) but no similar attempt has been undertaken to compare people's strategies for adapting to environmental change across community-based conservation initiatives located in regions vulnerable to climate change different from the Arctic. The latter would be meaningful in determining whether community-based conservation limits or expands the portfolio of people's adaptive strategies and in highlighting whether community-based conservation itself is adapting to the new risks and opportunities posed by climate change (e.g. changes in temperature and rainfall that can translate to changes in population numbers of certain species or changes in distributional patterns). In this regard, we believe that there is a need for further multidisciplinary comparative studies that focus on understanding the role that traditional ecological knowledge and community institutions can play in reducing local vulnerability and enhancing resilience in the context of community-based conservation. These should ideally account for both ecological and social dimensions of resilience to address past, present, and future climate variability and risks, and they could build, for example, on archival data, oral testimonies, and future scenarios, respectively (Walker et al. 2002, Gómez-Baggethun et al. 2012). These scenarios may then be used to describe and better understand the role of traditional ecological knowledge in shaping communities' adaptive capacity to cope with global environmental change, as well as the thresholds concerning adaptive capacity.

\section{CONCLUSION}

We set out to gather insights on how traditional ecological knowledge has influenced community-based conservation, and to explain how traditional ecological knowledge and other accompanying factors have influenced people's adaptive capacity and social-ecological systems resilience in such conservation contexts. Reviewed publications indicate the potential of traditional ecological knowledge in enhancing communities' ability to deal with global change. To cope with dynamic change, rural and indigenous communities often relied on their local experience and knowledge of environmental phenomena, cultural values and worldview, community networks, and local institutions while promoting biodiversity conservation and enhancing their livelihoods in self-regulated community-based conservation initiatives. In comanaged initiatives, local people also benefited from crossinstitutional arrangements and scientific knowledge that contributed to capacity building, knowledge generation through mutual learning, and trust building. Some of the reviewed cases also suggest, however, that traditional ecological knowledge has limitations in contributing to people's adaptive capacity in both types of community-based conservation initiatives. Traditional ecological knowledge can be undermined by community-based conservation when the latter results in imposed regulations and new management conflicts, whilst both traditional ecological knowledge and community-based conservation can also be undermined by the loss of institutional legitimacy and the imposition of formal regulations, as well as new market pressures, shifting behavior, and environmental change.

The review has allowed us to identify two major research gaps. On the one hand, there is a need for panel data on case study research documenting the effects of climate variability and shocks in the joint evolution of traditional ecological knowledge and community-based conservation, and their subsequent impacts on social-ecological resilience in temperate and tropical social-ecological systems. On the other, there is a need to expand the current focus on social variables and processes to explain changes in traditional ecological knowledge and adaptive capacity in the context of communitybased conservation towards a broader approach that pays attention to endogenous ecological dynamics and current patterns of environmental change. Only by fully comprehending existing synergies, conflicts, and trade-offs between traditional ecological knowledge, community-based conservation, and adaptive capacity in changing environments may we grasp the complexities and guide decision making for conservation across governance scales in meaningful ways.

Responses to this article can be read online at: http://www.ecologyandsociety.org/issues/responses. $\mathrm{php} / 5867$

\section{Acknowledgments:}

The authors thank three anonymous referees for helpful comments to an early version of this paper. The research has been funded through the European Union Seventh Framework Program FP7/2007-2013 under grant agreement $n^{\circ} 282899$ : "Assessing the effectiveness of community-based management strategies for biocultural diversity conservation (COMBIOSERVE)". Esteve Corbera gratefully acknowledges the financial support of the Spanish government's Research, Development and Innovation Secretariat through a 'Ramón y Cajal' research fellowship (RYC-2010-07183).

\section{LITERATURE CITED}

Adger, W. N. 2006. Vulnerability. Global Environmental Change 16:268-281.

Adger, W. N. 2007. Ecological and social resilience. Pages 78-90 in G. Atkinson, S. Dietz, and E. Neumayer, editors. Handbook of sustainable development. Elgar, Cheltenham, UK.

Adger, W. N., T. P. Huges, C. Folke, S. R. Carpenter, and J. Rockström. 2005. Social-ecological resilience to coastal 
disasters. Science 309:1036-1039. http://dx.doi.org/10.1126/ science. 1112122

Agarwal, B. 2001. Participatory exclusions, community forestry, and gender: an analysis for south Asia and a conceptual framework. World Development 29(10):1623-1648. http://dx.doi.org/10.1016/S0305-750X(01)00066-3

Armitage, D. R. 2003. Traditional agroecological knowledge, adaptive management and the socio-politics of conservation in Central Sulawesi, Indonesia. Environmental Conservation 30(1):79-90. http://dx.doi.org/10.1017/S0376892903000079

Armitage, D. R. 2005. Adaptive capacity and communitybased natural resource management. Environmental Management 35(6):703-715. http://dx.doi.org/10.1007/ s00267-004-0076-Z

Aswani, S., S. Albert, A. Sabetian, and T. Furusawa. 2007. Customary management as precautionary and adaptive principles for protecting coral reefs in Oceania. Coral Reefs 26:1009-1021. http://dx.doi.org/10.1007/s00338-007-0277$\underline{\mathrm{Z}}$

Berkes, F. 1993. Traditional ecological knowledge in perspective. Pages 1-9 in J. T. Inglis, editor. Traditional ecological knowledge: concepts and cases. International Program on Traditional Ecological Knowledge, Canadian Museum of Nature; and International Development Research Centre; Ottawa, Ontario, Canada.

Berkes, F. 1999. Sacred ecology: traditional ecological knowledge and resource management. Taylor \& Francis, Philadelphia, Pennsylvania, USA and London, UK.

Berkes, F. 2004. Rethinking community-based conservation. Conservation Biology 18(3):621-630. http://dx.doi.org/10.1111/ j.1523-1739.2004.00077.x

Berkes, F. 2007. Community-based conservation in a globalized world. Proceedings of the National Academy of Science 104(39):15188-15193. http://dx.doi.org/10.1073/ pnas.0702098104

Berkes, F. 2010. Devolution of environment and resources governance: trends and future. Environmental Conservation 37(4):489-500. http://dx.doi.org/10.1017/S037689291000072X

Berkes, F., J. Colding, and C. Folke. 2000. Rediscovery of traditional ecological knowledge as adaptive management. Ecological Applications 10(5):1251-1262. http://dx.doi. org/10.1890/1051-0761(2000)010[1251:ROTEKA]2.0.CO;2

Berkes, F., and N. J. Turner. 2006. Knowledge, learning and the evolution of conservation practice for social-ecological system resilience. Human Ecology 34(4):479-494. http://dx. doi.org/10.1007/s10745-006-9008-2

Brewer, J. F. 2011. Paper fish and policy conflict: catch shares and ecosystem-based management in Maine's groundfishery.
Ecology and Society 16(1):15. [online] URL:http://www. ecologyandsociety.org/vol16/iss1/art15/.

Brown, K. 2002. Innovations for conservation and development. The Geographical Journal 168:6-17. http://dx. doi.org/10.1111/1475-4959.00034

Campbell, L. M., and A. Vainio-Mattila. 2003. Participatory development and community conservation: opportunities missed for lessons learned? Human Ecology 31(3):417-437.

Cinner, J., M. J. Marnane, T. R. McClanahan, and G. R. Almany. 2006. Periodic closures as adaptive coral reef management in the Indo-Pacific. Ecology and Society 11 (1):31. [online] URL:http://www.ecologyandsociety.org/ vol11/iss $1 /$ art $31 /$.

Clark, D. A., D. S. Lee, M. M .R. Freeman, and S. G. Clark. 2008. Polar bear conservation in Canada: defining the policy problems. Arctic 61(4):347-360.

Colding, J., T. Elmqvist, and P. Olsson. 2003. Living with disturbance: building resilience in social-ecological systems. Pages 163-186 in F. Berkes, J. Colding, and C. Folke, editors. Navigating social-ecological systems: building resilience for complexity and change. Cambridge University Press, Cambridge, UK. http://dx.doi.org/10.1017/CBO9780511541957.011

Cotula, L. 2012. The international political economy of the global land rush: a critical appraisal of trends, scale, geography and drivers. Journal of Peasant Studies 39(3-4):649-680. http://dx.doi.org/10.1080/03066150.2012.674940

Coulthard, S. 2006. Developing a people centred approach to the coastal management of Publicat lake, a threatened lagoon in south India. PhD thesis. University of Bath, UK.

Coulthard, S. 2011. More than just access to fish: the pros and cons of fisher participation in a customary marine tenure (Padu) system under pressure. Marine Policy 35:405-412. http://dx.doi.org/10.1016/j.marpol.2010.11.006

Dauvergne, P., and K. J. Neville. 2010. Forests, food, and fuel in the tropics: the uneven social and ecological consequences of the emerging political economy of biofuels. Journal of Peasant Studies 37(4):631-660. http://dx.doi.org/10.1080/03$\underline{066150.2010 .512451}$

Dowsley, M. 2009. Community clusters in wildlife and environmental management: using TEK and community involvement to improve co-management in an era of rapid environmental change. Polar Research 28:43-59. http://dx. doi.org/10.1111/j.1751-8369.2008.00093.x

Dudley, N., editor. 2008. Guidelines for applying protected area management categories. International Union for Conservation of Nature and Natural Resources, Gland, Switzerland. http://dx.doi.org/10.2305/IUCN.CH.2008.PAPS.2. en 
Eakin, H. 2005. Institutional change, climate risk, and rural vulnerability: cases from central Mexico. World Development 33(11):1923-1938. http://dx.doi.org/10.1016/j.worlddev.2005.06.005

Evans, L. S., K. Brown, and E. H. Allison. 2011. Factors influencing adaptive marine governance in a developing country context: a case study of Southern Kenya. Ecology and Society 16(2):21. [online] URL:http://www.ecologyandsociety. org/vol16/iss2/art21/.

Fabricius, C., C. Folke, G. Cundill, and L. Schultz. 2007. Powerless spectators, coping actors, and adaptive comanagers: a synthesis of the role of communities in ecosystem management. Ecology and Society 12(1):29. [online] URL: http://www.ecologyandsociety.org/vol12/iss1/art29/.

Folke, C. 2006. Resilience: the emergence of a perspective for social-ecological systems analyses. Global Environmental Change 16:253-267. http://dx.doi.org/10.1016/j.

gloenvcha.2006.04.002

Folke, C., J. Colding, and F. Berkes. 2003. Synthesis: building resilience and adaptive capacity in social-ecological systems. Pages 352-387 in F. Berkes, J. Colding, and C. Folke, editors. Navigating social-ecological systems: building resilience for complexity and change. Cambridge University Press, Cambridge, UK. http://dx.doi.org/10.1017/CBO9780511541957.020

Folke, C., T. Hahn, P. Olsson, and J. Norberg. 2005. Adaptive governance of social-ecological systems. The Annual Review of Environment and Resources 30:441-473. http://dx.doi. org/10.1146/annurev.energy.30.050504.144511

Gadgil, M., F. Berkes, and C. Folke. 1993. Indigenous knowledge for biodiversity conservation. Ambio 22:151-156.

Gadgil, M., P. R. S. Rao, G. Utkarsh, P. Pramod, and A. Chhatre. 2000. New meanings for old knowledge: the People's Biodiversity Registers program. Ecological Applications 10 (5):1307-1317.

Gelcich, S., G. Edwards-Jones, M. J. Kaiser, and J. C. Castilla. 2006. Co-management policy can reduce resilience in traditionally managed marine ecosystems. Ecosystems 9:951-966. http://dx.doi.org/10.1007/s10021-005-0007-8

Gokhale, Y., R. Velankar, M. D. S. Chandran, and M. Gadgil. 1998. Sacred woods, grasslands and waterbodies as selforganized systems of conservation. Page 365-396 in P. S. Ramakrishnan, K.G. Saxena, and U. M. Chandrashekara, editors. Conserving the sacred for biodiversity management. Oxford and IBH Publishing, New Delhi.

Gómez-Baggethun, E., and V. Reyes-García. 2013. Reinterpreting change in traditional ecological knowledge. Human Ecology 41(4):643-647.
Gómez-Baggethun, E., V. Reyes-García, P. Olsson, and C. Montes. 2012. Traditional ecological knowledge and community resilience to environmental extremes: a case study in Doñana, SW Spain. Global Environmental Change 22 (3):640-650.

Goulden, M., L. O. Naess, K. Vincent, and W. N. Adger. 2009. Accessing diversification, networks and traditional resource management as adaptations to climate extremes. Pages 448-464 in W. N. Adger, I. Lorenzoni, and K. L. O'Brien. Adapting to climate change: thresholds, values and governance. Cambridge University Press, London and New York. http://dx.doi.org/10.1017/CBO9780511596667.029

Grant, S., and F. Berkes. 2007. Fisher knowledge as expert system: a case from the longline fishery of Grenada, the eastern Caribbean. Fisheries Research 84:162-170. http://dx.doi. org/10.1016/j.fishres.2006.10.012

Groves, C. R., E. T. Game, M. G. Anderson, M. Cross, C. Enquist, Z. Ferdaña, E. Girvetz, A. Gondor, K. R. Hall, J. Higgins, R. Marshall, K. Popper, S. Schill, and S. L. Shafer. 2012. Incorporating climate change into systematic conservation planning. Biodiversity and Conservation 21 (7):1651-1671. http://dx.doi.org/10.1007/s10531-012-0269-3

Holt-Gimenez, E. 2002. Measuring farmers' agroecological resistance after Hurricane Mitch in Nicaragua: a case study in participatory, sustainable land management impact monitoring. Agriculture, Ecosystems and Environment 93:87-105. http://dx.doi.org/10.1016/S0167-8809(02)00006-3

Janssen, M. A., J. M. Anderies, and E. Ostrom. 2007. Robustness of social-ecological systems to spatial and temporal variability. Society \& Natural Resources 20:307-322. http://dx.doi.org/10.1080/08941920601161320

Kalibo, H. W., and K. E. Medley. 2007. Participatory resource mapping for adaptive collaborative management at Mt. Kasigau, Kenya. Landscape and Urban Planning 82:145-158. http://dx.doi.org/10.1016/j.landurbplan.2007.02.005

Kennett, R., C. J. Robinson, I. Kiessling, D. Yunupingu, Mr Munungurritj, and D. Yununpingu. 2004. Indigenous initiatives for co-management of miyapunu/sea turtle. Ecological Management \& Restoration 5(3):159-166. http:// dx.doi.org/10.1111/j.1442-8903.2004.00204.x

Kennett, R., A. Webb, G. Duff, M. Guinea, and G. Hill, editors. 1998. Marine turtle conservation and management in northern Australia, proceedings of a workshop held at the Northern Territory University, Darwin 3-4 June 1997. Northern Territory University, Darwin, Australia.

Lauer, M., and S. Aswani. 2010. Indigenous knowledge and long-term ecological change: detection, interpretation, and responses to changing ecological conditions in Pacific Islands 
Communities. Environmental Management 45:985-997. http://dx.doi.org/10.1007/s00267-010-9471-9

Lebel, L., J. M. Anderies, B. Campbell, C. Folke, S. HatfieldDodds, T. P. Hughes. and J. Wilson. 2006. Governance and the capacity to manage resilience in regional social-ecological systems. Ecology and Society 11(1):19. [online] URL:http:// www.ecologyandsociety.org/vol11/iss1/art19/.

Mathew, S. 1991. Study of territorial use rights in small-scale fisheries: traditional systems of fisheries management in Publicat Lake, Tamil Nadu, India. FAO Fisheries Circular. Food and Agriculture Organization of the United Nations, Rome, Italy.

McClanahan, T. R., J. E. Cinner, J. Maina, N. A. J. Graham, T. M. Daw, S. M. Stead, A. Wamukota, K. Brown, M. Ateweberhan, V. Venus, and N. V. C. Polunin. 2008. Conservation action in a changing climate. Conservation Letters 1(2):53-59. http://dx.doi.org/10.1111/j.1755-263X.2$\underline{008.00008 \_1 . x}$

McLeod, E., B. Szuster, and R. Salm. 2009. Sasi and marine conservation in Raja Ampat, Indonesia. Coastal Management 37:656-676. http://dx.doi.org/10.1080/08920750903244143

Mehring, M., C. Seeberg-Elverfeldt, S. Koch, J. Barkmann, S. Schwarze, and S. Stoll-Kleemann. 2011. Local institutions: regulation and valuation of forest use-evidence from central Sulawesi, Indonesia. Land Use Policy 28:736-747. http://dx. doi.org/10.1016/j.landusepol.2011.01.001

Mishra, C., H. H. T. Prins, and S. E. Van Wieren. 2003. Diversity, risk mediation, and change in a trans-Himalayan agropastoral system. Human Ecology 31(4):595-609. http:// dx.doi.org/10.1023/B:HUEC.0000005515.91576.8f

Naess, L. O. 2012. The role of local knowledge in adaptation to climate change. WIRE's Climate Change 4(2):99-106. http://dx.doi.org/10.1002/wcc.204

Nelson, D. R., W. N. Adger, and K. Brown. 2007. Adaptation to environmental change: contributions of a resilience framework. Annual Review of Environmental Resources 32:395-419. http://dx.doi.org/10.1146/annurev. energy.32.051807.090348

Northeast Fisheries Science Center. 2008. Assessment of 19 northeast groundfish stocks through 2007: report of the $3^{\text {rd }}$ Groundfish Assessment Review Meeting, 4-8 August 2008. National Marine Fisheries Service, National Oceanic and Atmospheric Administration (NOAA), U.S. Department of Commerce, Woods Hole, Massachusetts, USA.

Olsson, P., and C. Folke. 2001. Local ecological knowledge and institutional dynamics for ecosystem management: a study of Lake Racken Watershed, Sweden. Ecosystems 4:85-104. http://dx.doi.org/10.1007/s100210000061
Ostrom, E. 1990. Governing the commons: the evolution of institutions for collective action. Cambridge University Press, Cambridge, UK. http://dx.doi.org/10.1017/CBO9780511807763

Pachauri, R. K., and A. Reisinger, editors. 2007. Climate change 2007: synthesis report. Contribution of Working Groups I, II and III to the Fourth Assessment Report of the IPCC. Intergovernmental Panel on Climate Change (IPCC), Geneva, Switzerland. http://dx.doi.org/10.1002/wene.36

Parlee, B., M. Manseau, and Lutsël K'é Dene First Nation. 2005. Using traditional knowledge to adapt to ecological change: Denésoliné monitoring of caribou movements. Arctic 58(1):26-37.

Peloquin, C., and F. Berkes. 2009. Local knowledge, subsistence harvests, and social-ecological complexity in James Bay. Human Ecology 37:533-545. http://dx.doi. org/10.1007/s 10745-009-9255-0

Perry, R. I., M. Barange, and R. E. Ommer. 2010. Global changes in marine systems: a socio-ecological perspective. Progress in Oceanography 87(1-4):331-337.

Pickering Sherman, K., J. Van Lanen, and R. T. Sherman. 2010. Practical environmentalism on the Pine Ridge Reservation: confronting structural constraints to indigenous stewardship. Human Ecology 38:507-520. http://dx.doi. org/10.1007/s10745-010-9336-0

Polar Bear Specialist Group IUCN/SSC (PBSG). 2005. Resolutions of the $14^{\text {th }}$ Working Meeting of the IUCN/SSC Polar Bear Specialist Group. Pages 57-60 in J. Aars, N. J. Lunn, A. E. Derocher. Polar bears, proceedings of the 14th Working Meeting of IUCN/SSC Polar Bear Specialist Group, 20-24 June 2005, Seattle, Washington, USA. Occasional Paper of the IUCN Species Survival Commission No. 32. IUCN, World Conservation Union, Gland, Switzerland and Cambridge, UK.

Rai, S. C. 2007. Traditional ecological knowledge and community-based natural resource management in northeast India. Journal of Mountain Science 4(3):248-258. http://dx. doi.org/10.1007/s11629-007-0248-4

Regehr, E. V., S. C. Amstrup, and I. Stirling. 2006. Polar bear population status in the southern Beaufort Sea. Open-File Report 2006-1337. U.S. Geological Survey, U.S. Department of the Interior, Reston, Virginia, USA.

Rerkasem, K., N. Yimyam, and B. Rerkasem. 2009. Land use transformation in the mountainous mainland southeast Asia region and the role of indigenous knowledge and skills in forest management. Forest Ecology and Management 257:2035-2043. http://dx.doi.org/10.1016/j.foreco.2008.11.008 
Scheidel, A., and A. H. Sorman. 2012. Energy transitions and the global land rush: ultimate drivers and persistent consequences. Global Environmental Change 22(3):588-595. http://dx.doi.org/10.1016/j.gloenvcha.2011.12.005

Shukla, S. R., and A. J. Sinclair. 2010. Strategies for selforganization: learning from a village-level community-based conservation initiative in India. Human Ecology 38:205-215. http://dx.doi.org/10.1007/s10745-010-9301-y

Tang, C.-P., and S.-Y. Tang. 2010. Institutional adaptation and community-based conservation of natural resources: the cases of the Tao and Atayal in Taiwan. Human Ecology 38:101-111. http://dx.doi.org/10.1007/s10745-009-9292-8

Toledo, V. M., B. Ortiz, L. Cortés, P. Moguel, and M. J. Ordóñez. 2003. The multiple use of tropical forests by indigenous peoples in México: a case of adaptive management. Conservation Ecology 7:9.

Tompkins, E. L., and W. N. Adger. 2004. Does adaptive management of natural resources enhance resilience to climate change? Ecology and Society 9(2):10. [online] URL:http:// www.ecologyandsociety.org/vol9/iss2/art10/.

Walker, B., S. Carpenter, J. Anderies, N. Abel, G. Cumming, M. Janssen, L. Lebel, J. Norberg, G. D. Peterson, and R. Pritchard. 2002. Resilience management in social-ecological systems: a working hypothesis for a participatory approach. Conservation Ecology 6(1):14.

Western, D., and R. M. Wright. 1994. Natural connections: perspectives in community-based conservation. Island Press, Washington, D.C., USA.

Wilk, R. 2002. Consumption, human needs and global environmental change. Global Environmental Change 12 (1):5-13. http://dx.doi.org/10.1016/S0959-3780(01)00028-0

Yurdi, Y., and S. Heiner. 2010. Managing conflict escalation in forestry: logging versus local community interests in Baru Pelepat village, Sumatra, Indonesia. International Journal of Biodiversity Science Ecosystem Services \& Management 6 (1-2):43-51. 
1) Ban, N. C., C. Picard, and A. C. J. Vincent. 2008. Moving toward spatial solutions in marine conservation with indigenous communities. Ecology and Society 13(1): 32.

2) Cinner, J.E., Basurto, X., Fidelman, P., Kuange, J., Lahari, R., and A. Mukminin. 2012. Institutional designs of customary fisheries management arrangements in Indonesia, Papua New Guinea, and Mexico. Marine Policy 36:278-285.

3) Grant, S., and F. Berkes. 2007. Fisher knowledge as expert system: A case from the longline fishery of Grenada, the Eastern Caribbean. Fisheries Research 84:162-170.

4) Herrmann, T. M., and M. C. Torri. 2009. Changing forest conservation and management paradigms: traditional ecological knowledge systems and sustainable forestry: Perspectives from Chile and India. International Journal of Sustainable Development \& World Ecology 16(6):392-403.

5) Lawrence, A., K. Paudel, R. Barnes, and Y. Malla. 2006. Adaptive value of participatory biodiversity monitoring in community forestry. Environmental Conservation 33(4):325-334.

6) Mbile, P., M. Vabi, M. Meboka, D. Okon, J. Arrey-Mbo, F. Nkongho, E. Ebong. 2005. Linking management and livelihood in environmental conservation: case of the Korup National Park Cameroon. Journal of Environmental Management 76:1-13.

7) Medley, K.E., and H.W. Kalibo. 2007. Global localism: Recentering the research agenda for biodiversity conservation. Natural Resources Forum 31:151-161.

8) Mishra, C., H.H.T. Prins, and S.E. Van Wieren. 2003. Diversity, Risk Mediation, and Change in a Trans-Himalayan Agropastoral System. Human Ecology 31(4):595-609.

9) Moller, H., F. Berkes, P.O. Lyver, and M. Kislalioglu. 2004. Combining science and traditional ecological knowledge: Monitoring Populations for co-management. Ecology and Society 9(3): 2.

10) Moller, H., J.C. Kitson, and T.M. Downs. 2009. Knowing by doing: Learning for sustainable muttonbird harvesting. New Zealand Journal of Zoology $36(3): 243-258$

11) Swemmer, L.K., and S. Taljaard. 2011. SANParks, people and adaptive management: Understanding a diverse field of practice during changing times. Koedoe 53(2-1017): 7

12) Terer, T., A.M. Muasya, F. Dahdouh-Guebas, G.G. Ndiritu, and L. Triest. 2012. Integrating local ecological knowledge and management practices of an isolated semi-arid papyrus swamp (Loboi, Kenya) into a wider conservation framework. Journal of Environmental Management 93:71-84.

13) Willebrand, T., C. Sandström, and T. Lundgren. 2006. Reaching for new perspectives on socio-ecological systems: exploring the possibilities for adaptive co-management in the Swedish mountain region. International Journal of Biodiversity Science \& Management 2(4):359-369.

14) Wollenberg, E., B. Campbell, E. Dounias, P. Gunarso, M. Moeliono, and D. Sheil. 2008. Interactive landuse planning in Indonesian rain-forest landscapes: reconnecting plans to practice. Ecology and Society 14(1): 35

Publications not describing TEK's contribution to adaptive management in CBC contexts

15) De Steven, D., and R. Lowrance. 2011. Agricultural conservation practices and wetland ecosystem services in the wetland-rich Piedmont-Coastal Plain region. Ecological Applications 21(3):S3-S17.

16) Elbakidze, M., P. K. Angelstam, C. Sandström, and R. Axelsson. 2010. Multi-stakeholder collaboration in Russian and Swedish Model Forest 
initiatives: adaptive governance toward sustainable forest management? Ecology and Society 15(2): 14.

17) Enserink, B., M. Patel, N. Kranz, and J. Maestu. 2007. Cultural factors as co-determinants of participation in river basin management. Ecology and Society 12(2): 24.

18) McClanahan, T.R., J.E. Cinner, N.A.J. Graham, T.M. Daw, J. Maina, S.M. Stead, A. Wamukota, K. Brown, V. Venus, and N.V.C. Polunin. Identifying Reefs of Hope and Hopeful Actions: Contextualizing Environmental, Ecological, and Social Parameters to Respond Effectively to Climate Change. Conservation Biology 23(3):662-671.

19) Ohl-Schacherer, J., E. Mannigel, C. Kirkby, G.H. Shepard Jr, and D.W. Yu. 2008. Indigenous ecotourism in the Amazon: a case study of 'Casa Matsiguenka' in Manu National Park, Peru. Environmental Conservation 35(1):14-25.

20) Thompson, P., P. Sultana, and R. Arthur. 2010. Integrating biological conservation into management: Community adaptive learning in the wetlands of Bangladesh. Biodiversity 11(1-2):31-38.

\section{Publications not based on case-study research}

21) Boyd, E. 2008. Navigating Amazonia under uncertainty: past, present and future environmental governance. Phiolosophical Transactions of The Royal Society 363:1911-1916.

22) Cinner, J. E., and S. Aswani. 2007. Integrating customary management into marine conservation. Biological Conservation 140:201-206.

23) Fabricius, C., E. Koch, and H. Magome. 2001. Towards strengthening collaborative ecosystem management: Lessons from environmental conflict and political change in southern Africa. Journal of the Royal Society of New Zealand 31(4):831-844.

24) Fabricius, C., C. Folke, G. Cundill, and L. Schultz. 2007. Powerless Spectators, Coping Actors, and Adaptive Co-managers: a Synthesis of the Role of Communities in Ecosystem Management. Ecology and Society 12(1):29.

25) Ferse, S.C.A., M. Mañez Costa, K. Schwerdtner Máñez, D.S. Adhuri, and M. Glaser. 2010. Allies, not aliens: increasing the role of local communities in marine protected area implementation. Environmental Conservation 37(1):23-34.

26) Folke, C., T. Hahn, P. Olsson, and J. Norberg. 2005. Adaptive governance of Social-Ecological Systems. Annual Review of Environment and Resources 30:441-473.

\section{Publication not referred to explicit conservation outcomes}

27) Armitage, D.R. 2005. Adaptive Capacity and Community-Based Natural Resource Management. Environmental Management 35(6):703-715.

28) Crate, S.A. 2006. Investigating Local Definitions of Sustainability in the Arctic: Insights from Post-Soviet Sakha Villages. Arctic 59(3):294-310.

29) Sandström, A., and C. Rova. 2010. Adaptive co-management networks: a comparative analysis of two fishery conservation areas in Sweden. Ecology and Society 15(3): 14. 